\title{
Seasonal Development of Dollar Spot Epidemics in Six Creeping Bentgrass Cultivars in Maryland
}

\author{
Christopher P. Ryan, Peter H. Dernoeden ${ }^{1}$, and Arvydas P. Grybauskas \\ Department of Plant Science and Landscape Architecture, University \\ of Maryland, 1112 H.J. Patterson, College Park, MD 20742
}

Additional index words. epidemiology, disease prediction model, pathogen, turfgrass

\begin{abstract}
This 3-year field study evaluated the incidence and severity of dollar spot (Sclerotinia homoeocarpa F.T. Bennett) in six creeping bentgrass (Agrostis stolonifera L.) cultivars maintained as a golf course fairway. Comparison of area under the disease progress curve (AUDPC) data clearly indicted two resistance groups among the six cultivars. 'Crenshaw' and 'Backspin' were classified as highly susceptible (HS) and the other four cultivars (i.e., 'Penncross', 'Providence', 'L-93', and '007') were classified as moderately susceptible (MS) to dollar spot. In all three study years, there were three epidemics that began in May. Data could not be collected in HS cultivars after the first epidemic in each year as a result of severe damage. In MS cultivars, the first epidemic ended and a second began between early July and late August. The second epidemic ended approximately mid-October and a third epidemic appeared in MS cultivars between late October and early December. The second epidemic was longest and most severe, and the third fall epidemic was least severe and of shortest duration. The first epidemic in HS cultivars developed up to two weeks earlier and progressed more rapidly and severely than in MS cultivars. A growing degree-day (GDD) model, using a base air temperature of $15^{\circ} \mathrm{C}$ and a start date of $1 \mathrm{Apr}$., was accurate in predicting the onset of the first epidemic in $\mathrm{HS}$ (60 to 70 GDD) and MS (105 to 115 GDD) cultivars during each of the three study years. Growing degree-day models are greatly influenced by the many microclimates found on golf courses and need to be evaluated for accuracy in diverse environments.
\end{abstract}

Dollar spot (Sclerotinia homoeocarpa) is a major disease of turfgrasses that is problematic for golf course superintendents throughout most of the United States. Creeping bentgrass (Agrostis stolonifera) is a commonly grown turfgrass species on golf course fairways in many regions of the United States. The disease appears on close-cut turf as spots usually $5.0 \mathrm{~cm}$ or less in diameter (Monteith and Dahl, 1932). Individual leaves of infected creeping bentgrass plants shrivel, curl, and turn a bleached white or straw color (Monteith and Dahl, 1932). In advanced stages, spots may become sunken and turf develops a pitted surface. During periods of high humidity when turf foliage is covered with dew, white, cottony mycelium may be present on infection centers.

Hall (1984) developed a dollar spot prediction model based on air temperature and precipitation in Ontario, Canada. He referred to dollar spot as occurring in a series of "steps." He defined a step as a point at which a decline in the epidemic rate was followed by an increase in epidemic rate. The model stated that a step in a dollar spot epidemic occurred after two consecutive wet days (days in which precipitation occurred) if the average air temperature for the period were $22{ }^{\circ} \mathrm{C}$ or greater or after three or more consecutive wet days if the

Received for publication 21 Nov. 2011. Accepted for publication 6 Jan. 2012.

${ }^{1}$ To whom reprint requests should be addressed; e-mailpd@umd.edu. average temperatures for the period were $15^{\circ} \mathrm{C}$ or greater. Hall (1984) tested the accuracy of the model by applying a fungicide curatively after infection conditions of the model were met. Using the model, he achieved equal control to that of a preventive program and reduced the number of fungicide applications. Burpee and Goulty (1986) tested Hall's (1984) model in Ontario, Canada, and found that acceptable disease control was not achieved because the model underestimated the number of infection periods.

Based on field observations in Ontario, Canada, Walsh (2000) developed a model to predict the onset of dollar spot using mean air temperature. This model stated that dollar spot would appear after 9 or $10 \mathrm{~d}$ of mean air temperatures exceeding $16^{\circ} \mathrm{C}$ after 1 May. Growth and development of pathogens and turfgrass hosts are greatly dependent on temperature. Growing degree-day models measure accumulated heat units, which are useful in predicting growth and development of many organisms (Ritchie and NeSmith, 1991). Growing degreeday models have been used to predict the emergence of some weeds and dead spot (Ophiosphaerella agrostis Dernoeden, Camara, O'Neill, van Berkum, et Palm) development in turfgrasses (Brosnan et al., 2010; Fidanza et al., 1996; Kaminski and Dernoeden, 2006). However, we are unaware of any studies using GDD to predict the onset of dollar spot.

Smith et al. (1989) observed that the incidence of dollar spot in cool-season grasses is seasonal and that one epidemic occurs in the spring or early summer and a second occurs in the fall. Hall (1984) and Walsh (2000), however, stated that there was only one annual dollar spot epidemic in Ontario. Although it is well known that dollar spot can be active between spring and fall (Smiley et al., 2005), we are unaware of any research-generated descriptions of the seasonal development and progression of dollar spot epidemics in the United States. A study of the epidemiology of dollar spot is thus warranted given the economic importance of this disease. Furthermore, it is unknown if steps in dollar spot epidemics vary in their incidence based on cultivar grown. Thus, the primary objective of this study was to describe the progression and severity of dollar spot epidemics in six creeping bentgrass cultivars in Maryland. A second objective was to determine if there were GDD relationships with the advent of dollar spot symptoms in spring.

\section{Materials and Methods}

This field study was conducted between 2008 and 2010 at the University of Maryland Paint Branch Turfgrass Research Facility in College Park, MD. Soil was a Keyport silt loam (fine, mixed, semiactive, mesic Aquic Hapludult) with an initial $\mathrm{pH}$ of 6.5 and $1.6 \%$ organic matter. Six creeping bentgrass cultivars (i.e., 'Backspin', 'Crenshaw', 'L-93', 'Penncross', 'Providence', and '007') were seeded into separate $3 \mathrm{~m} \times 3-\mathrm{m}$ plots arranged in a randomized complete block with four replications. The cultivars were selected based on National Turfgrass Evaluation Program (Beltsville, MD) dollar spot tolerance data (Kevin Morris, Director of NTEP, personal communication). Presumptively, 'L-93' and '007' were considered to have good resistance, 'Penncross' and 'Providence' moderate resistance, and 'Backspin' and 'Crenshaw' were judged to be highly susceptible. Soil was tilled, raked, and plots were seeded (100 kg seed/ha) on 5 Sept. 2007. A starter fertilizer $(18 \mathrm{~N}-24 \mathrm{P}-12 \mathrm{~K})$ was applied at a rate of $50 \mathrm{~kg} \mathrm{~N} / \mathrm{ha}$ at seeding and the area was kept moist until seedlings emerged on or $\approx 11$ Sept.

In all years, plots usually were mowed three times weekly to a height of $1.3 \mathrm{~cm}$ between 0700 and 0800 HR during the growing season and clippings were removed. On 8 May 2008, 10 Apr. 2009 and 1 Apr. 2010, urea (46N$0 \mathrm{P}-0 \mathrm{~K}$ ) was applied to all plots at a rate of 50 $\mathrm{kg} \mathrm{N} / \mathrm{ha}$. Nitrogen was applied at $7.3 \mathrm{~kg} \mathrm{~N} / \mathrm{ha}$ using urea every 2 weeks between mid-June and late August for a total of 36.5 to $43.8 \mathrm{~kg}$ $\mathrm{N} /$ ha/season. Between 1 and 18 Nov. 2008, 2009 , and 2010, an additional $50 \mathrm{~kg} \mathrm{~N} /$ ha from methylene urea was applied. Total amounts of $\mathrm{N}$ applied annually were between 137 and $144 \mathrm{~kg} \mathrm{~N} / \mathrm{ha}$. Water from an overhead irrigation system was applied as needed to prevent drought stress.

In 2008, each plot was bisected; half was randomly assigned a fungicide treatment and the other half was untreated. A fungicidetreated portion of each main plot was maintained in 2008 and 2009, but not in 2010, in the event dollar spot had severely damaged 
non-fungicide-treated areas. Data reported in this study were from the half plots $(1.5 \mathrm{~m} \times$ $3 \mathrm{~m}$ ) that remained untreated each season until data collection stopped.

Dollar spot pressure increased in the study area in late July 2008 and the non-fungicidetreated half of 'Backspin' and 'Crenshaw' plots became severely blighted (greater than 35 infection centers $/ \mathrm{m}^{2}$ ). As a result of high blight levels, the entire area of these cultivars was treated with iprodione 2SC [3-(3,5dichlorophenyl)- $N$-(1-methylethyl)-2, 4-dioxo1-imidazolidinecarboxamide; $3.0 \mathrm{~kg}$ a.i./ha] on 29 July and 15 Sept. to assist in turf recovery. Data collection stopped on 'Backspin' and 'Crenshaw' until May 2009. Similarly, 'Crenshaw' and 'Backspin' were severely damaged during the first epidemic in 2009 and 2010 and these plots were treated with fungicides on 29 June 2009 as previously described to assist recovery. No fungicides were applied in 2010. There was a late fall dollar spot epidemic beginning on 8 Nov. 2008. To stop the epidemic, the entire study area was treated with a tank mix of chlorothalonil 82.5WDG $(2,4,5,6$ tetrachloroisophthalonitrile; $10.1 \mathrm{~kg}$ a.i./ha), propiconazole 1.3 MEC \{Syngenta Crop Protection Inc., Greensboro, NC; 1-[2-(2,4dichlorophenyl)-4-propyl-1,3-dioxolan-2-ylmethyl]-1,2,4-triazole; $0.5 \mathrm{~kg}$ a.i./ha\}, and boscalid 70WG \{3-pyridinecarboxamide, 2chloro- $N$-[4' -chloro(1,1'-biphenyl)-2-yl]; BASF Corp., Research Triangle Park, NC; $0.43 \mathrm{~kg}$ a.i./ha on 14 Nov. 2008. A tank mix of iprodione $2 \mathrm{SC}(2.8 \mathrm{~kg}$ a.i./ha) and boscalid $70 \mathrm{WG}$ ( $0.43 \mathrm{~kg}$ a.i./ha), however, had to be applied to the area on 1 Dec. 2008 to stop the continuing late fall epidemic. The fungicide application made on 1 Dec. 2008 was the final dollar spot-targeted fungicide application made to the entire study area.

Pythium blight (Pythium spp.) was controlled preventively with mefenoxam $2 \mathrm{MEC}$ \{Syngenta Crop Protection, Inc.; [R]-2[(2,6dimethylphenyl) methoxyacetylamino] propionic acid methyl ester $\}$ on 10 and 28 July 2008 and 23 July 2010 at a rate of $0.77 \mathrm{~kg}$ a.i./ ha. Brown patch (Rhizoctonia solani Kuhn) appeared on 21 July 2008, 12 June 2009, and 8 June 2010 and flutolanil 70WP $\{N-[3-(1-$ methylethoxy) phenyl]-2-[trifluoromethyl] benzamide [Bayer Environmental Science, Research Triangle Park, NC; $64.0 \mathrm{~kg}$ a.i./ha]\} was applied to control the disease. Flutolanil was chosen because it has no activity on $S$. homoeocarpa.

Dollar spot developed naturally and uniformly across the study area in all years. Dollar spot was evaluated two to three times per week by counting the number of $S$. homoeocarpa infection centers (ICs) in each non-fungicidetreated subplot and data were converted to the number of $\mathrm{ICs} / \mathrm{m}^{2}$. When disease unexpectedly appeared in Nov. 2008, dollar spot was estimated visually using a $0 \%$ to $100 \%$ linear scale where $0=$ no blighting and $100 \%=$ entire plot area blighted, rather than by counting ICs. Infection centers, however, were counted during 2009 and 2010 fall epidemics.

Growing degree-days were computed using a base temperature $(\mathrm{Tb})$ of 10,12 , and $15^{\circ} \mathrm{C}$ beginning on 1 Apr. 2008, 2009, and 2010. Walsh (2000) developed a prediction model based on a 1 May start date in Ontario. Growing degree-days also were calculated using a 1 May start date in the current study. These data are presented for comparative purposes but are not discussed for brevity and for reasons noted subsequently. Base temperatures were chosen based on previous research showing that dollar spot could develop at average air temperatures as low as $10{ }^{\circ} \mathrm{C}$ but that disease development was promoted most when average daily air temperatures exceed $15{ }^{\circ} \mathrm{C}$ (Endo, 1963; Hall, 1984; Walsh, 2000). Because average daily air temperatures do not begin to consistently exceed $15{ }^{\circ} \mathrm{C}$ in College Park, MD, until early May in the average year, the 1 Apr. start date was chosen for critical discussion. The accumulation of GDD was calculated using the following equation (Ritchie and NeSmith, 1991):

$$
G D D=\sum_{i=1}^{n}\left(T a_{i}-T b\right)
$$

where $T a_{i}$ is the mean daily air temperature on Day $i ; T b$ is the base temperature; and $n$ is the number of days elapsed since initiating GDD. Any negative daily values were not used in the computation. Air temperature as well as precipitation data were obtained from a USDA weather station in the Beltsville Agricultural Research Center South Farm (BARC), which was located $\approx 0.6 \mathrm{~km}$ from the study site. Air temperatures were measured every $10 \mathrm{~s}$ and automatically averaged every 15 min at BARC. Average daily temperatures were calculated by averaging the 15 -min data over a standard 24-h period.

The experimental design was a randomized complete block with four replications. Area under the disease progress curve data were calculated using the trapezoidal method (Campbell and Madden, 1990), and all data were checked for violations of the assumptions of the analysis of variance (ANOVA) using the SAS Plot procedure (SAS Institute Inc., 2004). Plots of the residuals of the AUDPC values did not show abnormalities and data were not transformed. All data were subjected to ANOVA using PROC Mixed (SAS Institute Inc., 2004). Significantly different means were separated using Fisher's least significant difference at $P \leq 0.05$.

\section{Results}

Disease progress. In each year there were two major epidemics in the summer, each with multiple smaller "steps" (sensu Hall, 1984), where a period of disease decline was followed by an increase in disease severity (Figs. 1 to 3 ). Two cultivars, Crenshaw and Backspin, were extensively damaged every year limiting documentation of disease progress on them to the first summer epidemic. Comparison of AUDPC values clearly indicated two resistance groups for the six cultivars examined (Tables 1 to 3 ). 'Backspin' and 'Crenshaw' were significantly more susceptible to dollar spot than 'Penncross', 'L-93', '007', and 'Providence'. 'Crenshaw' was the most susceptible cultivar in 2009 and 2010. There were only a few instances when significant differences among 'Penncross', 'L-93', '007', and 'Providence' could be detected. Because the within-season patterns of disease progress were nearly identical among all cultivars and the magnitudes of the differences between two groups of cultivars were consistent every season, 'Crenshaw' and 'Backspin' were classified as HS and the remaining cultivars were classified as MS.

Disease onset for HS cultivars varied by $\approx 3$ weeks (i.e., between 4 and 23 May) over the three seasons (Figs. 1 to 3 ). Onset in MS cultivars followed onset in HS cultivars from $2 \mathrm{~d}$ to 2 weeks later. The peak (i.e., the greatest number of ICs $/ \mathrm{m}^{2}$ observed) of the first major seasonal epidemic varied in time and duration, but appeared to be similar for HS and MS cultivars in all but 2010. In 2010, disease progress in MS cultivars was a more gradual increase than in 2008 and 2009 so that a clear separation between the first and second epidemics was more difficult to discern. After a decline in dollar spot on or $\approx 5$ July, however, a clear increase in disease progress occurred between 16 and 28 July for all MS cultivars in 2010, which coincided with the recovery period after the peak in the epidemic in HS cultivars (Fig. 3). The disease progressed gradually reaching a range of 38 to $40 \mathrm{ICs} / \mathrm{m}^{2}$ on 28 July, 18 Aug., and 15 and 26 Sept. 2010 and then declined. Complete recovery from dollar spot did not occur in MS cultivars in any year before the advent of the second epidemic.

A second major summer dollar spot epidemic was readily apparent in 2008 and 2009 in MS cultivars with peaks in early Sept. 2008 and late Sept. 2009 (Figs. 1 and 2). The second epidemics were more severe than the first epidemics. As noted, in 2010, dollar spot generally increased after the step that coincided with turf recovery beginning on or $\approx 5$ July in HS cultivars (Fig. 3). The gradual increase was punctuated with several smaller steps in which there were increases of 5 to $12 \mathrm{ICs} / \mathrm{m}^{2}$ between 28 July and 26 Sept., but dollar spot remained at elevated levels without a strong recovery or a clear peak for $102 \mathrm{~d}$. In all years, during periods when dollar spot was inactive or declining in severity, the number of ICs decreased as a result of turf recovery; however, in pitted and more severely damaged ICs, there was no full recovery by the time data collection stopped in October.

In each year, dollar spot appeared a third time after late October in all MS cultivars (data not shown). Plots were rated only two (2009 and 2010) or three (2008) times in each fall epidemic because the study area was no longer being monitored daily and initially the fall reappearance of disease was unexpected. In 2008 only, dollar spot was evaluated as a percent of plot area blighted. Between 14 Nov. and 18 Dec. 2008, ratings among MS cultivars ranged from $3 \%$ to $7 \%$ of plot area blighted. In 2009, dollar spot was noted on 5 Dec. at which time there were between 6 and $15 \mathrm{ICs} / \mathrm{m}^{2}$ and these levels remained unchanged when data collection stopped on 18 Dec. In 2010 , 


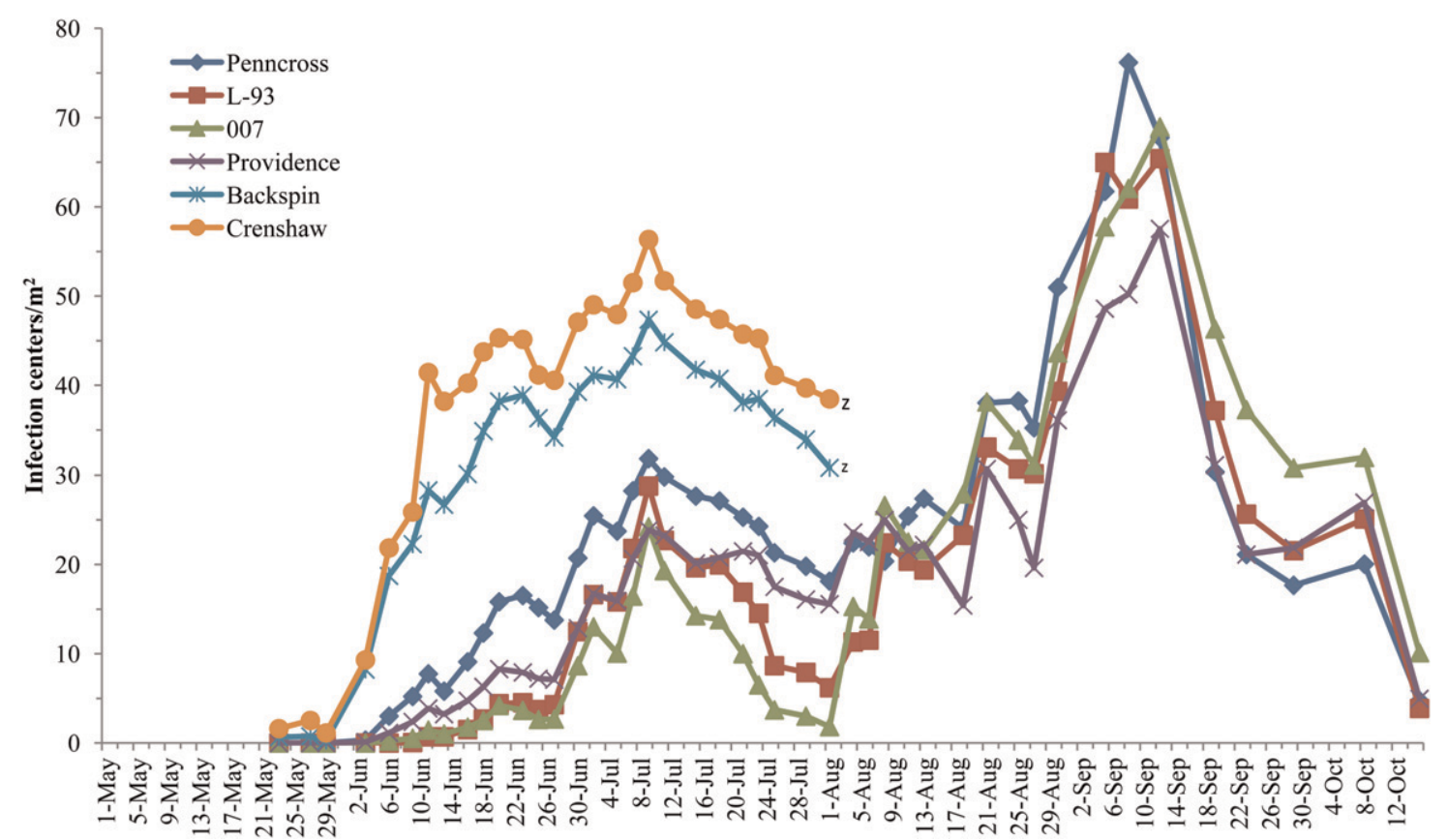

Fig. 1. Number of $S$. homoeocarpa infection centers in non-fungicide-treated plots of six creeping bentgrass cultivars between 1 May and 15 Oct. $2008 .{ }^{2}$ Denotes that data collection stopped as a result of extensive injury to the cultivar.

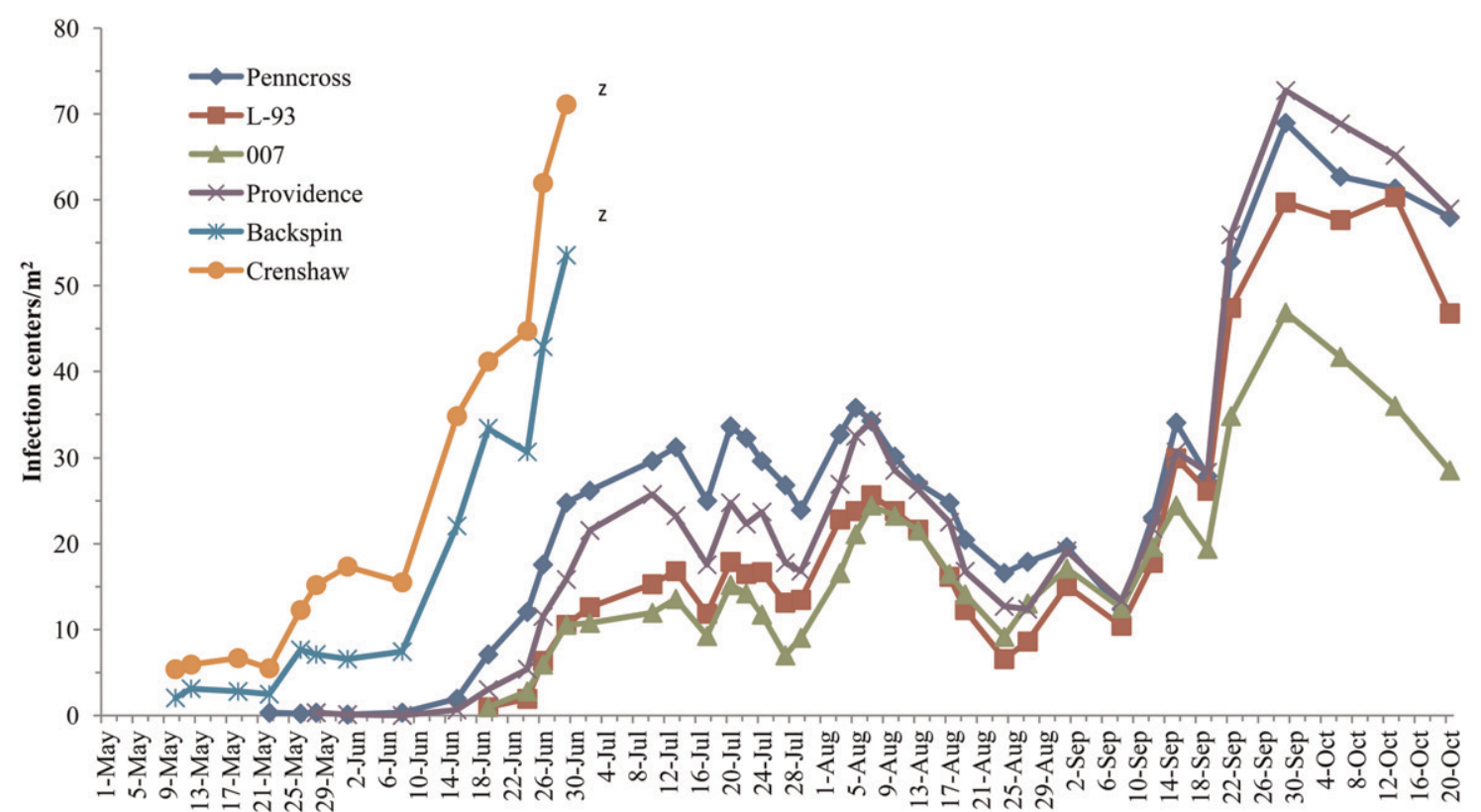

Fig. 2. Number of S. homoeocarpa infection centers in non-fungicide-treated plots of six creeping bentgrass cultivars between 1 May and 20 Oct. $2009 .{ }^{2}$ Denotes that data collection stopped as a result of extensive injury to the cultivar.

dollar spot appeared on 29 Oct., and there were between 10 and $15 \mathrm{ICs} / \mathrm{m}^{2}$ when data collection stopped on 9 Nov. Dollar spot development in 2008 was greater in '007', but there were no differences among MS cultivars in 2009 or 2010 (Tables 1 to 3 ).

Growing degree-days. Growing degreedays were calculated using three base temperatures $\left(10,12\right.$, and $\left.15^{\circ} \mathrm{C}\right)$ and a start date of 1 Apr. and 1 May. Because data from the 1 Apr. start date had the best fit, data from the 1 May start date are not discussed for brevity. The differences in GDD among base temperatures were similar in 2008,2009 , and 2010, but differences in the range of GDD among temperatures were smallest for the $15{ }^{\circ} \mathrm{C}$ base temperature (Table 4). At $10{ }^{\circ} \mathrm{C}$ and a start date of 1 Apr., dollar spot appeared after $\approx 193 \pm 36$ GDD and $303 \pm 33$ GDD for the HS and MS cultivars, respectively. At $12{ }^{\circ} \mathrm{C}$ and a start date of 1 Apr., dollar spot appeared after $\approx 130 \pm 20$ GDD and $212 \pm 23$ GDD for the HS and MS cultivars, respectively. At a base temperature of $15^{\circ} \mathrm{C}$ and a start date of 1 Apr., dollar spot symptoms appeared after $\approx 64 \pm 6 \mathrm{GDD}$ and $111 \pm 4$ GDD in HS and MS cultivars, respectively.
'Steps' as influenced by precipitation and average daily air temperature. To compare the accuracy of the Hall (1984) model, which is based on precipitation and daily average air temperature, steps in 'Penncross' epidemics were evaluated. There were only small differences among steps and cultivars in all 3 years. 'Penncross' was chosen to closely examine steps using criteria of the Hall (1984) model because it is among the most commonly grown and studied creeping bentgrass cultivars. As previously noted, an increase in dollar spot should occur after two consecutive wet 


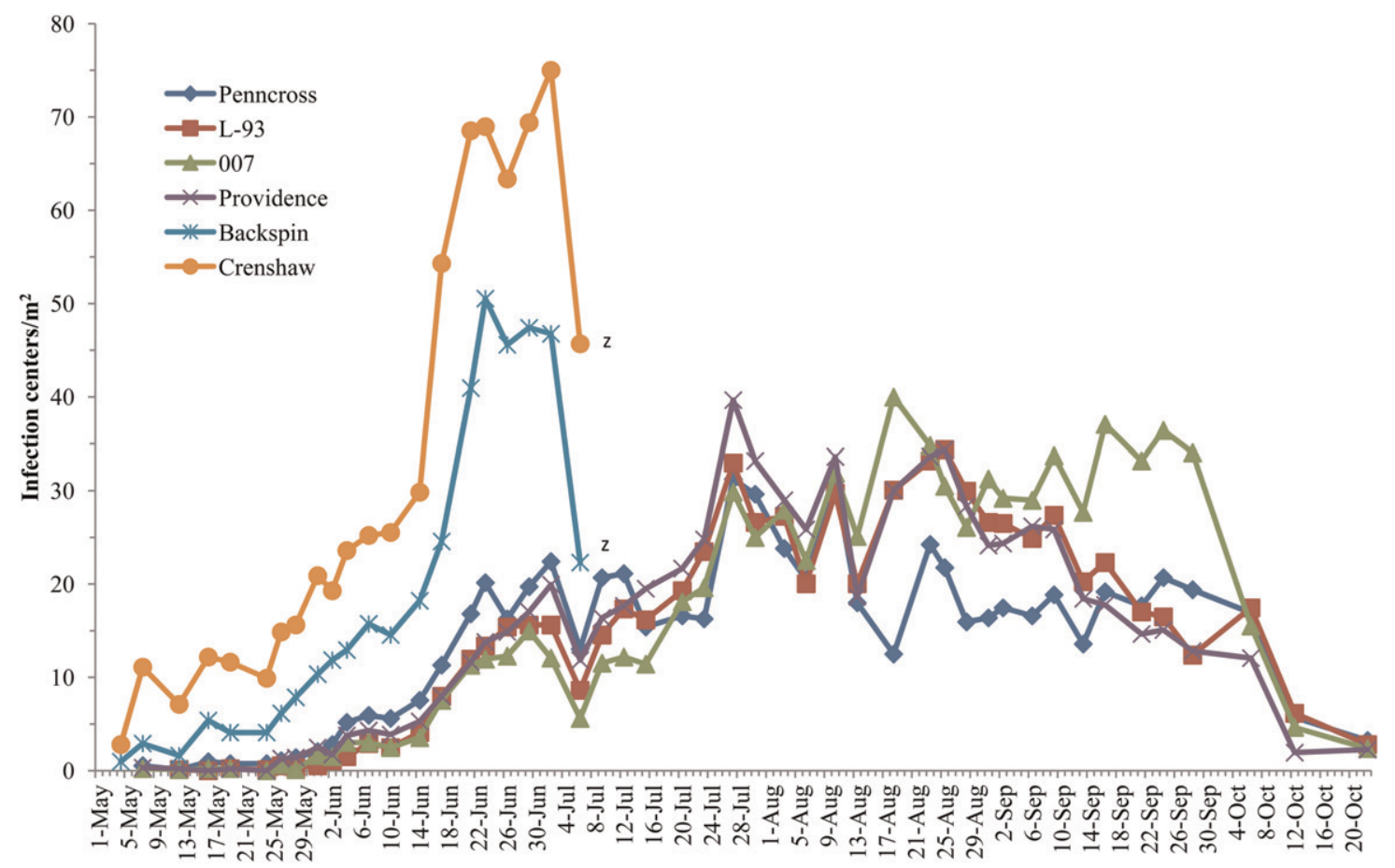

Fig. 3. Number of $S$. homoeocarpa infection centers in non-fungicide-treated plots of six creeping cultivars between 1 May and 22 Oct. $2010 .{ }^{\mathrm{z} D e n o t e s}$ that data collection stopped as a result of extensive injury to the cultivar.

Table 1. Area under the disease progress curve (AUDPC) for $S$. homoeocarpa infection center counts in six creeping bentgrass cultivars, 2008.

\begin{tabular}{lccc}
\hline & & \multicolumn{3}{c}{ AUDPC } \\
\cline { 2 - 4 } Cultivar & 23 May to 1 Aug. & 4 Aug. to 15 Oct. & 14 Nov. to 18 Dec. \\
\hline Penncross & $1081 \mathrm{~b}^{\mathrm{z}}$ & $2438 \mathrm{a}$ & $130 \mathrm{~b}$ \\
L-93 & $598 \mathrm{~b}$ & $2337 \mathrm{a}$ & $227 \mathrm{~b}$ \\
007 & $421 \mathrm{~b}$ & $2683 \mathrm{a}$ & $385 \mathrm{a}$ \\
Providence & $756 \mathrm{~b}$ & $2103 \mathrm{a}$ & $202 \mathrm{~b}$ \\
Backspin & $2102 \mathrm{a}$ & $\mathrm{y}$ & $\mathrm{y}$ \\
Crenshaw & $2527 \mathrm{a}$ & $\mathrm{y}$ & $\mathrm{y}$ \\
\hline
\end{tabular}

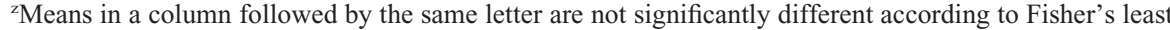
significant difference test at $P \leq 0.05$.

${ }^{y}$ Cultivar too severely blighted to be evaluated.

Table 2. Area under the disease progress curve (AUDPC) for S. homoeocarpa infection center counts in six creeping bentgrass cultivars, 2009.

\begin{tabular}{lcccc}
\hline & \multicolumn{4}{c}{ AUDPC } \\
\cline { 2 - 5 } Cultivar & 10 May to 29 June & 10 May to 24 Aug. & 27 Aug. to 20 Oct. & 5 Dec. to 18 Dec. \\
\hline Penncross & $172 \mathrm{c}^{\mathrm{y}}$ & $1731 \mathrm{a}$ & $2346 \mathrm{a}$ & $153 \mathrm{a}$ \\
L-93 & $43 \mathrm{c}$ & $959 \mathrm{bc}$ & $2073 \mathrm{ab}$ & $110 \mathrm{a}$ \\
007 & $45 \mathrm{c}$ & $839 \mathrm{c}$ & $1572 \mathrm{~b}$ & $120 \mathrm{a}$ \\
Providence & $90 \mathrm{c}$ & $1367 \mathrm{ab}$ & $2436 \mathrm{a}$ & $193 \mathrm{a}$ \\
Backspin & $738 \mathrm{~b}$ & $\mathrm{x}$ & $\mathrm{x}$ & $\mathrm{x}$ \\
Crenshaw & $1166 \mathrm{a}$ & $\mathrm{x}$ & $\mathrm{x}$ & $\mathrm{x}$ \\
\hline
\end{tabular}

${ }^{\mathrm{z}}$ Data represent the total period of the first epidemic for the moderately susceptible cultivars only because data collection stopped on 29 June in highly susceptible cultivars.

${ }^{y}$ Means in a column followed by the same letter are not significantly different according to Fisher's least significant difference test at $P \leq 0.05$.

${ }^{\mathrm{x}}$ Cultivar too severely blighted to be evaluated.

days if the average air temperature for the period were $22{ }^{\circ} \mathrm{C}$ or greater or after three or more consecutive wet days if the average temperatures for the period were $15{ }^{\circ} \mathrm{C}$ or greater (Hall, 1984). Using this model, criteria for a step in a dollar spot epidemic were met a total of 11 times in 2008 , but only six predicted steps corresponded to actual steps in the two summer epidemics. In 2009, Hall's
(1984) model predicted 14 steps, but only eight steps were observed in both epidemics Criteria for Hall's (1984) model were met nine times in 2010 , but 14 steps were observed during the summer epidemics. The model overestimated the number of steps in 2008 $(n=5)$ and $2009(n=6)$. In 2010, the model underestimated the number of steps $(n=6)$. Furthermore, the model predicted increases in disease three times in 2008; one time in 2009; and two times in 2010 in the first and second epidemics when the numbers of ICs were declining. Using these calculations, it was determined that the Hall (1984) model had an accuracy of 58\% in predicting steps.

\section{Discussion}

'Crenshaw' and 'Backspin' were most severely injured and were classified as HS cultivars. 'Penncross', 'Providence', 'L-93', and '007' generally exhibited similar levels of dollar spot injury and were classified as MS cultivars. Data collection was limited to the first epidemic in HS cultivars as a result of severe injury after the first epidemic. In all three study years, there were two epidemics in MS cultivars between May and midOctober and a third epidemic in MS cultivars between late October and early December Smith et al. (1989) stated that there are two dollar spot epidemics in late spring or early summer and again in the fall. Hence, the first two epidemics observed in the current study coincide with those reported by Smith et al. (1989), but in Maryland, a third epidemic may develop. Although this may be the first study to report that there is a third late fall epidemic in Maryland, it is well known to occur by area golf course superintendents. It also was elucidated that the second epidemic was longest and most severe and the third epidemic was least severe and of shortest duration in Maryland. Hall (1984) and Walsh (2000) report that only one epidemic occurs in Ontario, Canada, which likely is the result of longer periods of suboptimal temperatures for pathogen growth compared with Maryland and other more southern regions in the United States. 
Table 3. Area under the disease progress curve (AUDPC) for S. homoeocarpa infection center counts in six creeping bentgrass cultivars, 2010.

\begin{tabular}{lccc}
\hline & \multicolumn{3}{c}{ AUDPC } \\
\cline { 2 - 4 } Cultivar & 4 May to 6 July & 9 July to 22 Oct. & 29 Oct. to 9 Nov. \\
\hline Penncross & $458 \mathrm{c}^{\mathrm{z}}$ & $1859 \mathrm{~b}$ & $132 \mathrm{a}$ \\
L-93 & $305 \mathrm{c}$ & $2100 \mathrm{ab}$ & $125 \mathrm{a}$ \\
007 & $275 \mathrm{c}$ & $2676 \mathrm{a}$ & $142 \mathrm{a}$ \\
Providence & $360 \mathrm{c}$ & $2150 \mathrm{ab}$ & $152 \mathrm{a}$ \\
Backspin & $1168 \mathrm{~b}$ & $\mathrm{y}$ & $\mathrm{y}$ \\
Crenshaw & $2013 \mathrm{a}$ & $\mathrm{y}$ & $\mathrm{y}$ \\
\hline
\end{tabular}

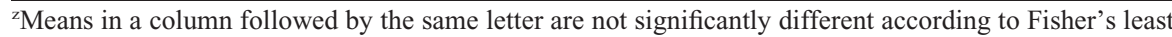
significant difference test at $P \leq 0.05$.

${ }^{\mathrm{y}}$ Cultivar too severely blighted to be evaluated.

Table 4. Growing degree-days (GDD) for predicting the onset of dollar spot epidemics in moderately (MS) and highly (HS) susceptible cultivars using base temperatures of 10,12 , and $15{ }^{\circ} \mathrm{C}$ and a start date of 1 Apr. or 1 May in 2008, 2009, and 2010 .

\begin{tabular}{|c|c|c|c|c|c|c|}
\hline & \multicolumn{6}{|c|}{ GDD } \\
\hline & \multicolumn{2}{|c|}{2008} & \multicolumn{2}{|c|}{2009} & \multicolumn{2}{|c|}{2010} \\
\hline & 1 Apr. & 1 May & 1 Apr. & 1 May & 1 Apr. & 1 May \\
\hline \multicolumn{7}{|l|}{$10^{\circ} \mathrm{C}$} \\
\hline HS & 229 & 120 & 171 & 72 & 180 & 53 \\
\hline MS & 334 & 225 & 306 & 207 & 270 & 143 \\
\hline \multicolumn{7}{|c|}{$12^{\circ} \mathrm{C}$} \\
\hline HS & 150 & 79 & 114 & 52 & 126 & 45 \\
\hline MS & 234 & 163 & 213 & 152 & 189 & 109 \\
\hline \multicolumn{7}{|l|}{$15^{\circ} \mathrm{C}$} \\
\hline $\mathrm{HS}$ & 62 & 32 & 60 & 28 & 70 & 33 \\
\hline MS & 112 & 82 & 115 & 82 & 105 & 68 \\
\hline
\end{tabular}

Other than differences in resistance, it was not previously reported if creeping bentgrass cultivars would behave differently during a dollar spot epidemic. That is, it was unclear if different cultivars exhibit different "steps" or different "peaks and valleys" in an epidemic. Data collected in all years revealed that the steps in all epidemics were similar, if not identical, for all cultivars evaluated, regardless of being HS or MS. 'Crenshaw' was more severely blighted than 'Backspin' in 2 (2009 and 2010) of the 3 years as measured by AUDPC. Among MS cultivars, there were no consistent differences in susceptibility. For example, 'Penncross' was more severely damaged than ' 007 ' in the first and second epidemics in 2009, whereas '007' was more severely damaged than 'Penncross' in the second epidemic in 2010. Dollar spot first developed between early and late May of each year. The disease appeared up to 2 weeks earlier and increased in severity more rapidly in HS compared with MS cultivars. Disease pressure was lowest in 2010 in MS cultivars, which may have been the result of numerous nights $(\mathrm{n}=26)$ when the average night temperatures were greater than $25{ }^{\circ} \mathrm{C}$ (data not shown). Future research should consider the impact of average night temperature on the incidence and severity of dollar spot.

The ability of all cultivars to eventually recover indicated that the pathogen does not extensively invade stems, but otherwise severely blights foliage and tillers on creeping bentgrass fairways in Maryland. Although numerous HS and some MS cultivar plants had died, many plants were able to recover either from axillary buds on stem bases or stolons. For example, on close inspection, a surviving stolon often was found in an apparently dead dollar spot pit. It was previously shown that $S$. homoeocarpa does not infect roots (Endo, 1963).

Growing degree-days calculated using a base temperature of $15^{\circ} \mathrm{C}$ and a start date of 1 Apr. were accurate in predicting the onset of the first epidemic beginning in May of each year. Using this base temperature was consistent with previous research demonstrating that dollar spot development begins at an average daily air temperature of $\approx 15^{\circ} \mathrm{C}$ (Endo, 1963; Hall, 1984; Walsh, 2000), which was further confirmed by GDD data. Using a base temperature of $15^{\circ} \mathrm{C}$ and a start date of 1 Apr., dollar spot appeared earlier in HS (60 to 70 GDD) than MS (105 to 114 GDD) cultivars. We are aware of only one other study involving the use of GDD in describing the development of a turf pathogen and disease. Kaminski and Dernoeden (2006) used GDD in their study of dead spot, which described the period in which pseudothecia production and patch diameter began to increase. It should be noted that the current study site was on relatively flat terrain, in full sun, and had good air circulation. Growing degree-day models for predicting plant diseases are typically weak in that they are strictly temperature-driven and often are developed under ideal conditions in a single location. Although rare, dollar spot can appear in late April in College Park, MD. Thus, it also is likely that diverse weather patterns unlike those experienced between 2008 and 2010 in this study would impact future GDD predictions of dollar spot in Maryland. Most golf courses have diverse microenvironments as a result of variations in topography, the presence or absence of trees and brush, and other natural features. Hence, the accuracy of this GDD model requires further testing in many diverse environments.

Comparing criteria of the Hall (1984) model with steps in the epidemics in 'Penncross' in the current study, it was determined that the model was $58 \%$ accurate. Burpee and Goulty (1986) found the Hall (1984) model to be ineffective in programming fungicide applications because it overestimated the number of infection periods. In the current study, the Hall (1984) model underestimated five to six steps in 2008 and 2009 and overestimated six steps in 2010. One to three times in all study years, the model predicted an increase in dollar spot when ICs were declining. These results generally corroborate those of Burpee and Goulty (1986). These findings also indicated that environmental factors other than precipitation and average daily temperature are integral components in the development of dollar spot epidemics.

Finally, it was interesting to note that ICs often declined and turf began to recover between the first and second epidemics in MS cultivars. The stasis in dollar spot progression in summer has received little discussion or study. Future researchers should investigate environmental parameters to determine why the first dollar spot epidemic ends and a second begins despite apparent conducive air temperatures and soil moisture.

\section{Literature Cited}

Brosnan, J.T., G.K. Breeden, and M.T. Elmore. 2010. Early and late postemergence control of dallisgrass in tall fescue. Online. Applied Turfgrass Science. DOI: 10.1094/ATS-20100312-02-RS.

Burpee, L.L. and L.G. Goulty. 1986. Evaluation of two dollar spot forecasting systems for creeping bentgrass. Can. J. Plant Sci. 66:345-351.

Campbell, C.L. and L.V. Madden. 1990. Introduction to plant disease epidemiology. John Wiley \& Sons, New York, NY.

Endo, R.M. 1963. Influence of temperature on rate of growth of five fungal pathogens of turfgrass and on rate of disease spread. Phytopathology 53:857-861

Fidanza, M.A., P.H. Dernoeden, and M. Zhang. 1996. Degree-days for predicting smooth crabgrass emergence in cool-season turfgrasses. Crop Sci. 36:990-996.

Hall, R. 1984. Relationship between weather factors and dollar spot of creeping bentgrass. Can. J. Plant Sci. 64:167-174.

Kaminski, J.E. and P.H. Dernoeden. 2006. Dead spot severity, pseudothecia development, and overwintering of Ophiosphaerella agrostis in creeping bentgrass. Phytopathology 96:248254.

Monteith, J. and A.S. Dahl. 1932. Turfgrass diseases and their control. Bulletin of the United States Golf Association 12:85-188.

Ritchie, J.T. D.S. NeSmith. 1991. Temperature and crop development, p. 5-29. In: Hanks, J. and J.T. Ritchie (eds.). Modeling plant and soil systems. ASA, Madison, WI.

SAS Institute Inc. 2004. SAS Online Doc. Version 9.2, SAS Institute, Cary, NC.

Smiley, R.W., P.H. Dernoeden, and B.B. Clarke. 2005. Compendium of turfgrass diseases. 3rd Ed. American Phytopathological Society, St. Paul, MN

Smith, J.D., N. Jackson, and A.R. Woolhouse. 1989. Fungal diseases of amenity turf grasses. E. \& F.N. Spon, New York, NY.

Walsh, B. 2000. Epidemiology and disease forecasting system for dollar spot caused by Sclerotinia homoeocarpa. F.T. Bennett. PhD diss., Department of Environmental Biology, University of Guelph, Canada. 